Paedagogia Christiana

2/46 (2020) - ISSN 1505-6872

Dol: http://d.doi.org/10.12775/PCh.2020.025

Sylwia Zydek*

ORCID: 0000-0001-9630-5957

Wrocław, Poland

\title{
The Role and Importance of the Eucharistic Crusade and the Sodality of Our Lady in the Process of Religious Education according to St Ursula Ledóchowska (1865-1939)
}

\section{Rola i znaczenie Krucjaty Eucharystycznej i Sodalicji Mariańskiej w procesie wychowania religijnego według św. Urszuli Ledóchowskiej (1865-1939)}

\begin{abstract}
The article is an attempt to present the educational work undertaken by Ursula Ledóchowska (1865-1939) in the context of her creation of groups of the Eucharistic Crusade (addressed to children up to 15 years old) and The Sodality of Our Lady (for youth). Mother Ledóchowska established the first detachment of the Eucharist Crusade in Poland in 1925 in Pniewy. In addition to the Crusade circles, she also founded sodality groups in Poland as well as in Russia and Scandinavia. Ledóchowska was aware that by bringing young people together in religious organisations it would be possible to shape their characters, hearts and consciences. She perfectly understood that only formation work is able to build the foundations of the Catholic Church and, in turn, the Polish society she dreamed of - religious

* Dr. Sylwia Zydek, Pontifical Faculty of Theology in Wrocław, Poland; email: sylwia. zydek@op.pl.
\end{abstract}


God-oriented, patriotic, devoted to her homeland, and hardworking. The Eucharistic Crusade and the Sodality of Our Lady would become 'educational tools' in achieving this goal.

Keywords: Eucharistic Crusade; Sodality of our Lady; religious education.

Abstrakt: Artykuł jest próbą analizy pracy wychowawczej, podejmowanej przez Urszulę Ledóchowską (1865-1939) w kontekście tworzenia przez nią grup Krucjaty Eucharystycznej, adresowanej do dzieci do 15. roku życia oraz Sodalicji Mariańskiej przeznaczonej dla młodzieży. Matka Ledóchowska powołała do istnienia w 1925 roku w Pniewach - pierwszy w Polsce - hufiec Krucjaty Eucharystycznej. Obok kół Krucjaty zakładała także grupy sodalicyjne, tak w Polsce, jak i w Rosji oraz w Skandynawii. Ledóchowska miała bowiem świadomość, że zrzeszając młodych ludzi w organizacje religijne, będzie kształtować ich charaktery, serca i sumienia. Rozumiała doskonale, iż tylko praca formacyjna jest w stanie budować gmach Kościoła katolickiego, a tym samym społeczeństwa polskiego. Marzyła, by społeczeństwo to było religijne i zorientowane na Boga, patriotyczne, czyli oddane ojczyźnie, i pracowite. Swoistym „narzędziem wychowawczym” w osiągnięciu tego celu stać się miały właśnie Krucjata Eucharystyczna oraz Sodalicja Mariańska.

Słowa kluczowe: Krucjata Eucharystyczna; Sodalicja Mariańska; wychowanie religijne.

\section{Introduction}

Beginning with the foundations of faith in God, early Christianity developed the principles of religious education, introducing new concepts and values. They became the foundation of Catholic education and the Church became their depositary, ultimately shaping consciences by talking about what was right and what was wrong. Obviously, this was not its only task because the teaching role of the Church has been understood for centuries; here, it is sufficient to mention the Jesuit colleges that exist all over the world. By teaching and educating, the Church took responsibility for man, for 'the whole man', that is for his soul and body. He was to experience full humanity from the perspective of earthly life and, after death, deserve heaven. Huge numbers of Catholic educators understood exactly the tasks that lay before them: to show young people how to live in order to achieve happiness and salvation. 


\section{St. Ursula Ledóchowska - teacher at the end of the $19^{\text {th }}$ and beginning of the $20^{\text {th }}$ centuries}

One hugely influential Catholic educator was Julia Ledóchowska (religious name Ursula), who lived at the turn of the $19^{\text {th }}$ and $20^{\text {th }}$ centuries. She was born in Lower Austria on April 16, 1865, the daughter of Count Antoni Ledóchowski (Zdybicka, 2003) ${ }^{1}$ and Józefina née Salis-Zizers ${ }^{2}$ (Marzani, 1989). At home, she received a thorough education, especially in the humanities (history of Poland, painting, music) and in the field of foreign languages. In 1874, the Loosdorf family moved to St. Poelten. There, together with her sisters, ${ }^{3}$ she studied at the Salary of English Ladies, i.e. the Institute of the Blessed Virgin Mary (Ledóchowska J., 1998).

In 1883, the family moved to Lipnica Murowana. Aged 18, she settled very quickly there, tried to help the local population, and after her father's death in 1885 she took over a lot of her mother's farm duties. However, from early childhood, she had considered joining a monastery. She confided these desires only to her brother Włodzimierz. ${ }^{4}$ She realised this plan in 1886 yet, as she recalled, 'the pawn did not get where it wanted' (Ledóchowska U., 2007); this was because Julia had no intention of joining the Ursuline nuns and preferred the hearts or missionaries. Nevertheless, the time she spent in Kraków, in Starowiślna Street was a period of growth both in her vocation and numerous other talents. At the beginning of her monastic journey, she was sent to France to obtain a diploma entitling her to teach French in secondary schools (Schmidt, 2011). In addition to working at school, she took painting lessons and made copies of works by great masters (Ledóchowska J., 1984a); she also held the position of monastery superior for one term and in 1905 she opened the first home for female students in Poland (Bojarska, 1989; Zyzak, 2015). As Małgorzata Krupecka notes, 'The twenty-one years spent there are a time for her religious and pedagogical formation, and

${ }^{1}$ Antoni Ledóchowski (1823-1885). He was born in Warsaw. In 1839, after his mother had died, he moved with his father to Munich. There he studied law and painting. He served in the Austrian army for a short time. His first wife died in 1861, leaving three sons, and the wedding with Józefina took place in 1862. Antoni died after returning from Austria in Lipnica Murowana.

2 Josephine (1831-1909). She came from an old family of Swiss knights, the Salis-Zizers.

3 Maria Teresa (1863-1922) and Maria (1867-1879).

4 Włodzimierz Ledóchowski (1866-1942), General of the Jesuits from 1915 until 1942. 
then a period of gaining rich educational experience and, of course, spiritual maturation' (Krupecka, 2003).

In 1907, Ursula Ledóchowska left for St. Petersburg, without a habit or any outward signs of belonging to the clergy, as Countess Julia Ledóchowska. Here, as per the instructions of Fr. Konstanty Budkiewicz, she ran a boarding school at the Polish gymnasium of St. Katarzyna (Ledóchowska J., 1984a, 1998).

Her stay on the Neva was marked by hard work and the creation of a completely new quality in the institution she found, which prospered both materially and educatively. The time she spent in Russia, later split with her author's school in Merentähti (Krupecka, 2003), was a difficult period, but it gave Ledóchowska many opportunities to test her pedagogical undertakings. Groups of young people associated with the Sodality were created in each new location. However, the outbreak of the war forced the countess to seek refuge in Stockholm. Her stay there, spanning the period from 1914 to 1920, was marked by hard work for the sake of her homeland (Krupecka, 2014), which was slowly rising from its decline, and for the sake of young people in both Poland and Scandinavia. Key initiatives during this time include such the Language Institute in Djursholma, the Aalborg Economic School, an orphanage for Polish orphans, and a day-room for street children. After Poland regained independence, Ledóchowska decided to return to her homeland. She bought land in Lubocześnica in 1920 and, together with her sisters and orphans, returned to Poland to start working for the good of Polish society. The formation of the new congregation was not an easy task, but it was not possible to return to the Kraków Ursulines. Later attempts to create a union failed and therefore Mother Ledóchowska knew that she had to complete the process of creating a new community of sisters. In 1923, Pius XI approved the Constitutions for a period of seven years so that they would be finally confirmed in 1930, laying the legal foundations for the new Congregation of the Ursuline Sisters of the Agonizing Heart of Jesus (Zdybicka, 2003).

Grey Ursulines (Zdybicka, 1968), ${ }^{5}$ as she called her sisters colloquially, were to go wherever nobody else wanted to work. They were supposed to teach, educate, heal, look after, and show God to all those that no one had

5 'The spirituality and organisational structure of the new religious community has had its own clearly defined shape from the very beginning. It clearly differs from the forms of religious life and apostolic activity of nuns hitherto sanctified by tradition. An important novelty introduced by Mother Ledóchowska consists of breaking the barrier that has so often separated the religious state from the secular life. With her inherent acuity of vision, she perceives the 
cared for before. This was the charism of the new religious congregation, the sisters of which tried (as best they could) to deal with the poverty of the interwar period. Indeed, until her death in 1939 Mother Ursula worked intensively not only in Poland, but also in Italy and France. Knowing that the sisters were not able to cover all the facilities alone, she asked her former students from the Institute in Lubocześnica for help and used an article in Saint Olaf's Bell to encourage young women to devote a year or two of their lives to work for the poor and needy. Those who signed up were placed in institutions through Poland (Zdybicka, 2003). The Congregation was developing dynamically; the sisters took special care of the children and young people because they understood that the youngest would be the future of the Church and Poland (Zydek, 2019).

In order to briefly characterise Ledóchowska's pedagogy, one should pay attention to the goal she set for her pupils, which was love for God. She believed that Jesus was the best teacher (Ledóchowska U., 1926). Indeed, she repeated that 'in the hands of Jesus, under the guidance of Jesus, with Jesus in his heart, the child will grow up to be a good, virtuous Christian' (Ledóchowska J., 1998). As emphasised by one student, 'The mother's educational work was based on a deep religious life' (Jankowska, 2004, pp. 3-4) - for her religious identity was the key principle of life, yet she knew perfectly well that her charges should build their own lives. She believed that she needed to prepare children to work on themselves in order to be useful members of society who love people and are responsible, independent, courageous, persistent and hardworking (Olbrycht, 2020). She also knew that the formation of children in the Eucharistic Crusade, and then young people in the Sodality of Our Lady, could help in shaping these characters.

\section{The Eucharistic Crusade in Mother Ursula's educational work}

During the Second Republic of Poland, alongside parents, peers, school and religious communities, various organisations were also heavily involved in the upbringing of a young person. One which had a significant impact on the children and youth of that period was the Eucharistic Crusade (Topij-Stem-

most pressing need of time and does not hesitate to meet the world that has dictated her new forms of religious apostolate.' (Zdybicka, 1968) 
pińska, 2009). The crusade was officially launched in November 1915 in Bordeaux. Its original purpose was to pray for the French soldiers at the front. The Crusade was initially overseen by the Jesuit Albert Bessers, and its full name was the Eucharistic Crusade of the Apostolate of Prayer (Topij-Stempińska, 2009; Kurosz, 2012; Guzewicz, 2004).

'The first Crusade post in Poland was established in 1925 thanks to the efforts of Mother Ursula Ledóchowska, the general superior of the Ursuline Sisters S.J.K. (Of the Aging Heart of Jesus), in Pniewy, in Greater Poland' (Statute of the Eucharistic Crusade of Children in Poland, 1938). The next circles were created in the same year in Swarzędz near Poznań, Łódź, Sieradz, Góra Kalwaria, Gołańcza, and Szymanów. With time, further circles were established in Mielżyn, Ruda Wielka, Otorów and Goździchów. From 1927, the management of the Crusade in Poland was taken over by the Jesuits because they had assumed charge in other countries. Father Josef Bok was appointed director and the secretariat was moved to Kraków, as was the editorial office of Host (Topij-Stempińska, 2009).

Mother Ledóchowska was well aware that the foundation of the Crusade should become the foundation of religious education, so wherever she could she spoke about this movement. Participating in the Catholic Congress in Warsaw, she described it as follows:

... now, let me say a few words about an institution that can be of great help to you, Christian mothers, in raising your children with Jesus and for Jesus, because it develops their piety by encouraging them to act, to fight evil, and to follow great ideals. This institution - which has achieved miraculous results, has opened millions of children's hearts for Christ and today is conquering children's hearts all over the globe in a triumphal march, but unfortunately in our Poland it is barely taking its first timid steps - is the Eucharistic Crusade of Children ... The Eucharistic Crusade is the Apostolate of Prayer for children from the youngest to 15-18 years of age ... Here is a brief statute of the Eucharistic Crusade:

1. The goal of K.E. is to extend the Kingdom of Jesus' Heart all over the world.

2. The measures for this are as follows:

a) Working on developing a righteous and strong character.

b) Deepening the love for the Blessed Sacrament of the Altar through frequent reception of Holy Communion.

c) Prayer, works of zeal, sacrifices.

The team morally applies to the daily Holy Communion. 
The squad is obligated to frequent Holy Communion (two-three times a week).

The team is obligated to Holy Communion (weekly).

The team is obligated to Holy Communion (monthly).

3. Only children who behave perfectly in school or outside of school can belong to K.E.

4. Each unit chooses a patron.

5. Every K. E. man dedicates his day to the Most Sweet Heart of Jesus every morning.

6. All K.E. members gather every day for Holy Communions, prayers, works of zeal and offerings to the Treasury of Jesus' Heart.

7. Each member subscribes to the magazine Advocates of the Eucharistic Crusade and reads it diligently.

8. Each K.E. member wears the badge of the crusaders, especially when the Crusade occurs collectively, for example at its meetings and parades.

9. General meetings of members are usually held every two weeks (Ledóchowska U., 1926).

From this passage it is clear that Ledóchowska considered the Crusade to be one of the most effective 'tools' of religious education for children and youth in Poland after the First World War. The action plan on the basis of which the groups - i.e. the Crusade's troops - were created was an ambitious scenario that had to be followed in order to develop in children attachment to the Church and faithfulness to its values on the one hand, and to shape their character and encourage self-education, which is an extremely important element in the educational process, on the other.

The Crusade operated on the basis of all available means of didactic to influence on the child. In order to implement its basic tasks and assumptions, various forms of activity were undertaken. The methods were selected so that they were attractive to children (Topij-Stempińska, 2009). It was vital that students remained engaged and it was necessary to work with them in a way that would make them curious and active. Crusade meetings were divided into departmental, host and general meetings. Their goal was to create a kind of theoretical foundation for the practical shaping of 'little crusaders', with meetings beginning with the greeting of the Crusade: 'Christ, reign over us! - Always and everywhere!' Subsequently, a prayer was performed. During the meetings, the prayerful intention of the month was explained and the programme of work on character was outlined. If necessary, occasional events related to celebrations or saints were prepared. The meetings were 
to be short, but interesting, and aids to conduct them could be found in the Host or the Eucharistic Crusade Guide. During the meetings, talks aimed at introducing the lifestyles of exemplary peers were important and examples of good and bad behaviour were then given (Topij-Stempińska, 2009).

In addition to regular meetings, there were also Crusade Days. Children from a neighbouring parish or school could be invited to such a ceremony. Such meetings were held mainly in May and June. The model for Crusade Days was probably the meeting that took place in Łódź (Mother Ledóchowska reported that about 2,000 children took part). The ceremony was very solemn, and each Crusade wheel arrived with its own standard. After the Mass celebrated by the local bishop, the children went to breakfast and a solemn academy:

After the academy was over, the children formed a march in fours with banners... The procession lasted an hour to the Church of Our Lady of Victory... There was an altar in front of the church, where the Blessed Sacrament was transferred in the monstrance. The beautiful ceremony ended with a blessing. The first Crusade Day in Poland was lovely. (Ledóchowska J., 1984b, pp. 177$-178)$

These celebrations produced vivid memories among the children and it also seems that the whole formation they received changed their lives for the better. One of Ledóchowska's students ${ }^{6}$ from Pniewy recalled her activities in this field as follows:

She founded the Eucharistic Crusade of Children in order to revive enthusiasm in young souls and, through diligent work on herself, prepare them to be future apostles of the Church, the foundation of Catholic society. Despite the sheer volume of duties, she wrote novels for children in order to influence their souls and published the organ of the Eucharistic Advocate Crusade. (Górnicka, 1991, pp. $250-251)^{7}$

${ }^{6}$ Maria Górnicka, a student at the school in Pniewy from 1923-1924.

7 The Eucharistic Advocate contained articles and formation materials for children. For example, the Eucharistic Advocate from 1935, XI, No. 1 included information on the purchase of uniforms, a banner, and subscription to the magazine. Moreover, the main content contained formation information, a short story by Ursula Ledóchowska entitled 'Among the forests and marshes,' treasuries of particular Crusade groups (in their treasuries, the Knights write down the good deeds that they have done for Jesus), competitions, etc. 
Where the mother herself could not start Crusade groups, circles were formed around former students who themselves belonged to the organisation. One of these individuals was Halina Jankowska:

After leaving the St. Olaf in Pniewy, where I got to know the Eucharistic Crusade, organised by Mother in Poland, I founded it for children in Sarnów. Mother Ledóchowska gave me valuable advice not to bore children with God, but to stimulate them, entice them and inflame them with love - 'Lord God - Love itself should be attractive to children rather than something distant, boring which one has to be forced into ... But it must flow from the heart of an apostle. If the fire in his soul does not burn in vain, he will try to transfer it to others.' (Jankowska, 2004, pp. 71-72)

Of course, the Crusade groups, thanks to their formal guardians, i.e. the Jesuit Fathers, involved many people; for example, in the Archdiocese of Vilnius itself there were 75,000 children. However, there would not have been such a huge number of children involved if it were not for the enthusiasm and enthusiasm of Mother Ledóchowska and the people who moderated the movement, be it in schools or parishes. In 1936, there were 1,820 establishments in Poland with over 100,000 members. Moreover, just before World War II, there were already 2,500 clubs containing 200,000 children. This widespread proliferation of opportunities was how Mother Ledóchowska (1984b [1932]) encouraged children to join the Crusade: 'The Eucharistic Crusade makes me strong in faith; it pours into my heart this joy of belonging to Christ's soldiers and protects me from fear of human judgment, and therefore I want to and will belong to the Eucharistic Crusade.' Elsewhere, she said:

Jesus wants you to be sanctified. You have to fight your evil inclinations, you have to fight your virtues... So what does the Lord Jesus want from you? He wants to see you as the virtue of obedience to your parents and superiors. He is so obedient on the cross until death, obedient in the tabernacle to the words of the priest - so try to bring Jesus the sacrifice of obedience. Obedience is the best sacrifice... What else does Jesus want from you? He would like to see you unanimously doing good for your companions, he would like to see you as diligent in fulfilling your duties (Ledóchowska U., 1984a[1930]).

All the guidelines included in the Crusade action plan had one goal: to create a man devoted to God from an early age who is faithful to his ideals 
and who lives in a relationship with Jesus. This overriding attitude is clearly demonstrated by Beata Topij-Stempińska (2009):

Religious education proposed by the Eucharistic Crusade was not only based on the theoretical assumptions of Catholic educational thought, but also contained proposals for specific behaviours and standards of conduct. Indeed, it was assumed that genuine Christianity was first and foremost a 'life of faith' and not merely belief or words spoken. It was believed that the young generation had to be taught to live according to the principles preached by Christ. It was primarily about deepening faith in God and following his commandments.

The author further explains:

The most important dimension of the activities undertaken was to shape the child as a unique, sensitive and active person. The basic principle of this type of upbringing was to teach young people to seek, perceive and discover different experiences. The next step was to make choices based on the acquired knowledge, own thoughts and conviction about God's help.

These quotes clearly echo Mother Ledóchowska's beliefs regarding the education and shaping of children and adolescents. Kazimierz Kucharski, an aptly named Jesuit, recalled Mother Ledóchowska ten years after her death on Vatican Radio:

By introducing the Eucharistic Crusade as a complement to religious education at the level of kindergartens and primary schools, she gave the religious life of Polish children the most appropriate direction, captivating their hearts with a heroic attitude in life: knights of Eucharistic Jesus. (Kucharski, 2004, pp. 94-96)

\section{Marian Sodality: Continuation of the religious formation of young people}

The Sodality was essentially a natural continuation of the formation of children who 'grew up' from the Crusade. Although like the Crusade it was developing under the auspices of the Jesuits, in many places where she established her houses and institutions Mother Ledóchowska also created groups of female Sodality members. 
'The Jesuit Marian Sodalities date back to the beginning of the $16^{\text {th }}$ century. The first was founded in the Roman college in 1563 by the Flemish Jesuit cleric Jan Leunis' (Sprutta 2005). It was officially erected in Italy in 1584 by Gregory XIII in the church of Il Gesù (Morawski, 1935). In Poland, the first congregation was established in Braniewo in 1571. There were two or three Sodalities in large colleges, associating students of all ages (Grochowski, 1975). The Church based both education and sodalisation work on three assumptions: developing perfection, the obligation to save others, and defending God's truths in social and civic life. As specified by Aldona Zakrzewska (2012), 'Sodality was a school of true social life characters and deep friendship.' An important feature of Sodality was the fact that it emphasised educational activities (Liaushuk, 2014).

Persons undertaking formation in Sodality committed themselves to the best and most diligent fulfilment of the duties of Catholics and sons of the motherland, acting as good family members and exemplary students and colleagues (Zakrzewska, 2012). Congregations also put emphasis on social activity, teaching self-government and managing a common fund (Hlebionek $\&$ Berode, 2002) as well as work that could generally be called cultural and educational, e.g. choirs, amateur theatres, reading rooms and organised tours. Of course, the most important issue in the formation carried out in Sodality was the love of Mary, the Mother of Jesus: 'Per Mariam ad Jesum' (Krzysztofek, 2013, 2018). As highlighted by Sprutta (2016), Sodalis were required to attend daily mass, weekly confession, daily meditation and daily examination of conscience. They were also expected to take holy communion often, with the recommendation being every two weeks. Understandably, Sodality drew from Ignatian spirituality.

The first Sodality was founded by Mother Ledóchowska in 1906 in a student dormitory in Kraków, although it should be remembered that in 1887 Sodality has already been established in the Ursuline school by mother Stanisława Sulkowska (Puszka, 2009, 2018). The first moderator of the Students' Sodality was Fr. Josef Tuszowski, who was also the confessor and spiritual director of St Ursula. In St Petersburg, after taking over a boarding school, Ledóchowska tried to raise its 'spiritual level' and therefore founded Sodality a year after her arrival. The first admission of girls to its ranks took place in May 1908, with Mother Ursula herself conducting the meetings. The group of boarding girls was joined by schoolgirls from the city, as well as ladies from the Polish community in St Petersburg (Ledóchowska J., 1984a). Furthermore, while staying in Stockholm in 1915, Ledóchowska founded the Sodality of Our Lady. This organisation continued to be active during the 
1940s, which is proof of its vitality and confirms that it was a movement with strong roots that enjoyed great popularity. It turns out that it was not only an organisation associating pupils and students, but also adults who wanted to develop spiritually and improve through self-education. Similar Sodalition groups are mentioned by Katarzyna Krzysztofek (2013), who has studied the Sodality of men operating in Kraków at the turn of the $19^{\text {th }}$ and $20^{\text {th }}$ centuries.

Mother Ledóchowska understood that in the Sodality, both young people and adults would find everything necessary for their internal development. Consequently, she wanted the Sodalities to exist wherever there were young people with a desire to follow Christian ideals and ready to improve the quality of their spiritual life. One of the previously mentioned pupils from Pniewy, Maria Górnicka, left a testimony about Ledóchowska's activities in this respect:

She was spreading the Sodality of Our Lady with care. Alone in the St. Olaf conducted meetings with us, in Poznań she organised the circles of former Pniewski Sodalis. She often attended these meetings herself. She called us to active charity and apostolic help for our brothers in the borderlands. (Górnicka, 2004, pp. 54-56)

Mother Ursula was aware that the educational programme of the Sodality was a perfect continuation of the process of religious education on which the Eucharistic Crusade was based. That is why it was so important for her to create Sodalition groups wherever possible. Internal work and self-education, which was extremely important for the mother, were 'included' in the programme of Sodality. Indeed, one of Mother Ursula's core beliefs was that religiously educated children, as part of their work in the Eucharistic Crusade, need continuation in their further religious formation. There had to be a continuity in the upbringing process until adulthood.

Groups were created everywhere, and the Sodality founded by Ledóchowska in Łódź was recalled many years later by Janina Cegielowa, a student of the Household Teachers' Seminar: 'membership in the Sodality was completely voluntary - and here each of us declared ourselves. She did it when she felt the need and became convinced that she could afford such additional duties of inner life' (2004, pp. 10-12). Here, the educational model was designed around bringing them closer to the Mother of Jesus. The ideals of simplicity, generosity, purity and humility were intended to shape the students for life. 
Following the Second World War, many parishes wanted to revive their religious life and the Crusade groups were established, the first of which began in 1946. Unfortunately, in 1949 such activities were prohibited by the authorities (Topij-Stempińska, 2009). The Sodality of Our Lady reactivated in a similar way but unfortunately in 1949, like many other Catholic associations, it ceased to exist.

\section{Conclusions}

An important element in the life of the Church is the implementation of her educational function, which focuses on education in faith ... The rich practice of carrying out educational activities by consecrated persons has been developing for centuries in accordance with the charisms of individual congregations, reaching for tradition and responding to contemporary challenges (Opiela, 2017, pp. 155-179).

In the context of this statement by Maria Opiela, it is easier to understand why various Catholic educators 'used' (and continue to use) organisations that brought together children and youth. The process probably looks different today because it must take into account the changing social situation. However, groups of young people in the Church are still evident today and are indicative of a specific formation.

It is worth mentioning here that, following their reactivation in 1980, Sodalition circles now function in many parishes in a similar manner to the organisation of children and young people established in 1985 (Zydek, 2015), which was founded on the Eucharistic Crusade, i.e. the Eucharistic Youth Movement.

Mother Ledóchowska understood perfectly well that the movements created for children and adolescents are indispensable in the process of religious formation. This is because it is impossible to imagine a method of education where requirements are not imposed and in which young people do not have to make effort to mould themselves. The most important factor, however, is that the contemporary young person, despite developing a slightly different context compared to his peers a hundred years ago, is subject to certain universal laws and principles regarding religious education and, more broadly, education for self-education. These principles are still as relevant as in the times of Mother Ursula. 


\section{References}

Adamska, J. (2004). Ze wspomnień o matce Urszuli Ledóchowskiej. Archiwum Główne Sióstr Urszulanek SJK, Pniewy (pp. 3-4).

Bojarska, T. (1989). W imię trzech krzyży. Opowieść o Julii Urszuli Ledóchowskiej i jej Zgromadzeniu. Warszawa: Pax.

Cegielowa, J. (2004). Wspomnienie z pobytu w Pniewach w 1929 roku. Archiwum Główne Sióstr Urszulanek SJK, Pniewy (pp. 10-12).

Górnicka, M. (1991). Ojczyźnie i rodzinie. In A. Szafrańska i T. Szafrański (Eds.), Miłość krzyża się nie lęka... Listy Julii Ledóchowskiej-bł. Urszuli i wspomnienia o niej (pp. 250-253). Warszawa: Pax.

Górnicka, M. (2004). Wspomnienie o Matce Urszuli Ledóchowskiej. Archiwum Główne Sióstr Urszulanek SJK, Pniewy (pp. 71-72).

Grochowski, L. (1975). Kościół Katolicki wobec wychowania szkolnego w Polsce w latach 1918-1930. Rozprawy z Dziejów Oświaty, 18, 165-186.

Guzewicz, W. (2004). Krucjata Eucharystyczna w międzywojennej diecezji łomżyńskiej. Studia Teologiczne, 22, 165-186.

Hlebionek, M. \& Berode, A. (2002). Początki Sodalicji Mariańskiej przy kolegium jezuickim w Toruniu (nieznany dokument Klaudiusza Aquavivy z 14 IX 1606 r.). Rocznik Toruński, 29, 189-196.

Jankowska, H. (2004). Moje wspomnienia o Matce Urszuli Ledóchowskiej. Archiwum Główne Sióstr Urszulanek SJK, Pniewy (pp. 71-72).

Krupecka, M. (2003). Polka i Europejka. Ząbki: Apostolicum.

Krupecka, M. (2014). Działalność Julii Urszuli Ledóchowskiej na rzecz niepodległości Polski w latach 1914-1920 na terenie krajów skandynawskich. In B. Świtalska \& M. Żuławik (Eds.), Różnymi drogami do niepodległości. Studia z Historii Najnowszej (pp. 35-56). Warszawa: UKSW.

Krzysztofek, K. (2013). Sodalicja mężczyzn w Krakowie na przełomie XIX i XX w. Studia z Prawa Wyznaniowego, 16, 137-160.

Krzysztofek, K. (2018). Statuty sodalicji mariańskich kobiet w Krakowie w dwudziestoleciu międzywojennym. Studia z Dziejów Państwa i Prawa Polskiego, 21, 157-179.

Kucharski, K. (2004). Wspomnienie o Matce Urszuli Ledóchowskiej. Archiwum Główne Sióstr Urszulanek SJK, Pniewy (pp. 94-96).

Kurosz, J. (2012). Od Krucjaty Eucharystycznej do Eucharystycznego Ruchu Młodych w Polsce. Roczniki Pastoralno-Katechetyczne, 59(4), 281-306.

Ledóchowska, U. (1926). Krucjata Eucharystyczna dzieci. In Księga pamiątkowa Zjazdu Katolickiego w Warszawie 28-30 sierpnia 1926 (pp.136-142). Warsza- 
wa: Główny Komitet Obchodu 200-letniej rocznicy kanonizacji Św. Stanisława i Zjazdu Katolickiego w Warszawie.

Ledóchowska, U. (1984 [1930]a). Ofiarna miłość dziecięcego serca wobec Eucharystycznego Jezusa. Odczyt wygłoszony na I Ogólnopolskim Kongresie Eucharystycznym w Poznaniu. 1930 r. In J. R. Bar (Ed.), Polscy święci (pp. 262-264), Warszawa: ATK.

Ledóchowska, U. (1984b [1932]). Dlaczego należę do Krucjaty? Przemówienie wygłoszone na Kongresie Eucharystycznym w Radomiu 26 VI 1932. In J. R. Bar (Ed.), Polscy święci (p. 261). Warszawa: ATK.

Ledóchowska, U. (2007). Byłam tylko pionkiem na szachownicy... Wspomnienia z lat 1886-1924. Częstochowa: Edycja Świętego Pawła.

Ledóchowska, J. (1984a). Życie dla innych. Błogosławiona Urszula Ledóchowska 1865-1939. Poznań: Pallotinum.

Ledóchowska, J. (1984b). Zarys biografii błogosławionej Urszuli Ledóchowskiej. In J. R. Bar (Ed.), Polscy święci (pp. 12-141). Warszawa: ATK.

Ledóchowska, J. (1998). Życie i działalność Julii Urszuli Ledóchowskiej. Warszawa: Michalineum.

Liaushuk, W. (2014). Sodalicja Mariańska kolegium jezuickiego w Grodnie w latach 1630-1773. Stowo Ojczyste, 3(153), 6-18.

Marzani, M. (1989). Matka świętych. Józefina z Salis Zizers - Ledóchowska 1831-1909. Wrocław: Wydawnictwo Wrocławskiej Księgarni Archidiecezjalnej.

Morawski, M. (1935). 350 lat pracy duchowej sodalicji w świecie, a w szczególności w Polsce. Przegląd Powszechny, 205, 331-340.

Opiela, M. (2017). Praca wychowawczo-edukacyjna osób konsekrowanych jako element misji Kościoła. In A. Dudek \& R. Kantor (Eds.), Życie konsekrowane znakiem wiarygodności Kościoła (pp. 155-179). Kraków: Wydawnictwo Naukowe Uniwersytetu Papieskiego Jana Pawła II.

Olbrycht, K. (2020). Pedagogia św. Urszuli Ledóchowskiej. Poznań: Święty Wojciech.

Puszka, A. (2009). Sodalicje mariańskie uczniów szkól średnich Krakowa w XIX wieku i w okresie II Rzeczpospolitej. Roczniki Humanistyczne, 57, 121-158.

Puszka, A. (2018). Sodalicja mariańska na ziemiach polskich wobec wojny i odzyskania niepodległości w 1918 roku. Teka Komisji Historycznej PAN-KUL, XV, 45-59.

Schmidt, S. K. (2011). Św. Urszula Ledóchowska, Polska i Europejka. Językowy wymiar osobowości. Warszawa: Towarzystwo Kultury Języka.

Sprutta, J. (2005). Wizerunek Maryi w pobożności sodalicji Mariańskiej w świetle czasopisma „Sodalis Marianus”. Salvatoris Mater, 7(2), 383-391.

Sprutta, J. (2016). Początki Sodalicji Mariańskiej w jezuickich kolegiach dawnej Rzeczpospolitej. Studia Bydgoskie, 10, 295-305. 
Statut Krucjaty Eucharystycznej Dzieci w Polsce [Statute of the Eucharistic Crusade of Children in Poland] (1938). Wiadomości Diecezjalne Eódzkie, 3, 79-80.

Topij-Stempińska, B. (2009). Działalność edukacyjna Krucjaty Eucharystycznej w Polsce międzywojennej. Kraków: WAM.

Zakrzewska, A. (2012). Edukacja szkolna dzieci i młodzieży szkolnej okresu międzywojennego źródłem humanizacji życia społecznego. Paedagogia Christina, 2/30, 47-68.

Zdybicka, Z. J. (1968). Julia Ledóchowska (Matka Urszula). In B. Bejza (Ed.), W nurcie zagadnień posoborowych, t. 2, (pp. 437-438). Warszawa: Wydawnictwo Sióstr Loretanek- Benedyktynek.

Zdybicka, Z. J. (2003). Otworzyć serce. Apostolstwo matki Urszuli Ledóchowskiej. Warszawa: Verbinum.

Zydek, S. (2015). Urszulanki Serca Jezusa Konającego we Wrocławiu - 50 lat służby i radości. Łódzkie Studia Teologiczne, 24/3, 89-115.

Zydek, S. (2019). Julia-Urszula Ledóchowska: system odziaływań wychowawczych na przykładzie szkoły w Pniewach w latach 1920-1939. In K. Kuszak \& R. Chęciński (Eds.), Od inspiracji ku przyszłości. Wybrane zagadnienia wspótczesnej edukacji (pp. 269-296). Poznań: Wydawnictwo Uniwersytetu Adama Mickiewicza.

Zyzak, W. (2015). Powołanie i misja rodziny w Kościele i świecie współczesnym czego może uczyć św. Urszula Ledóchowska? In M. Krupecka \& W. Misztal (Eds), Św. Urszula Ledóchowska: Kobieta w Kościele i społeczeństwie. Kraków: Wydawnictwo Jana Pawła II. 